Jurnal Manajemen dan Bisnis, Volume 1, No. 2, Januari 2020

\title{
PENGARUH DEBT EQUITY RATIO, CURRENT RATIO, MATURITY DAN SIZE TERHADAP BOND RATING (STUDI PADA PERUSAHAAN PERBANKAN YANG TERDAFTAR DI BEI PERIODE 2012-2017)
}

\author{
Ekka Pratama \& Revan Andhitiyara
}

\begin{abstract}
ABSTRAK
Penelitian ini dilakukan untuk menganalisis pengaruh Debt Equity Ratio, Current Ratio, Maturity dan Size terhadap Bond Rating Perusahaan Perbankan di Bursa Efek Indonesia periode 2012-2017. Penelitian menggunakan data sekunder dari laporan keuangan tahunan perusahaan terpilih yang diunduh dari website resmi Bursa Efek Indonesia. Teknik pengambilan sampel menggunakan metode purposive sampling. Sampel pada penelitian ini terdiri dari 11 perusahaan perbankan. Analisis data dilakukan dengan pengujian hipotesis baik secara parsial maupun secara simultan. Metode analisis yang digunakan adalah regresi logistik biner dengan tingkat signifikansi $5 \%$ dan $10 \%$. Berdasarkan hasil penelitian menunjukkan bahwa secara parsial variabel Debt Equity Ratio (DER) tidak berpengaruh signifikan terhadap Bond Rating, Current Ratio (CR) berpengaruh positif dan signifikan terhadap Bond Rating, Maturity tidak berpengaruh signifikan dan Size berpengaruh negatif dan tidak signifikan terhadap Bond Rating. Secara simultan, diperoleh nilai signifikansi sebesar 0,002 , karena nilai signifikansi lebih kecil dari 0,05 maka seluruh variabel berpengaruh terhadap Bond Rating. Berdasarkan hasil penelitian, diharapkan mampu menjadi bahan evaluasi bagi bank terkait dengan Bond Ratingdan hubungannya dengan DER, CR, Maturity, dan Size sehingga pihak bank bisa melakukan pengolahan dengan baik.
\end{abstract}

Kata Kunci: Debt Equity Ratio, Current Ratio, Maturity, Size, dan Bond Rating.

\section{ABSTRACT}

This research is aims to analyze the influence of Debt Equity Ratio, Current Ratio, Maturity and Size on Banking Company Bond Ratings on the Indonesia Stock Exchange for the period 2012-2017. The study uses secondary data from the annual financial statements of selected companies downloaded from the official website of the Indonesia 
Stock Exchange. The sampling technique uses purposive sampling method. The sample in this study consisted of 11 banking companies.

Data analysis was performed by testing hypotheses both partially and simultaneously. The analytical method used is binary logistic regression with a significance level of 5\% and 10\%. Based on the results of the study showed that partially Debt Equity Ratio (DER) variables did not significantly influence Bond Rating, Current Ratio (CR) had a positive and significant effect on Bond Rating, Maturity had no significant effect and Size had a negative and not significant effect on Bond Rating. Simultaneously, a significance value of 0.002 is obtained, because the significance value is smaller than 0.05, then all variables affect the Bond Rating.

Based on the results of the study, it is expected to be able to be an evaluation material for banks related to Bond Rating and its relationship with DER, CR, Maturity, and Size so that the bank can do the processing properly.

Keywords: Debt Equity Ratio, Current Ratio, Maturity, Size, and Bond Rating.

\section{Pendahuluan}

Sektor perbankan memiliki peranan yang penting dalam kemajuan perekonomian suatu negara, karena sektor perbankan memiliki fungsi sebagai perantara antara pihak yang kelebihan dana dengan pihak yang kekurangan dana. Perbankan mampu menggerakan kegiatan bisnis dan investasi melalui penyediaan modal sehingga pertumbuhan ekonomi yang tinggi negara tersebut dapat tercapai. Pada umumnya investasi pada pasar keuangan dibagi menjadi dua bagian yaitu pasar modal dan pasar uang. Dimana dalam penelitian ini akan membahas tentang pasar modal yaitu obligasi.

Obligasi sebagai alat investasi memberikan

pendapatan yang tetap bagi pihak investor dan merupakan sekuritas yang lebih aman bila dibandingkan dengan sekuritas lain seperti saham. Pada obligasi pemegang obligasi memiliki hak pertama atas aset perusahaan jika perusahaan tersebut mengalami likuidasi. Hal ini dikarenakan adanya suatu kontrak perjanjian untuk melunasi obligasi kepada investor. Analisis keuangan merupakan faktor yang menentukan peringkat obligasi. Dengan melakukan analisis rasio keuangan, dapat diketahui posisi keuangan perusahaan dalam suatu periode tertentu, baik harta, kewajiban, modal maupun hasil usaha yang telah dicapai untuk beberapa periode, selain itu dapat digunakan untuk mengetahui kelemahankelemahan apa saja yang menjadi kekurangan perusahaan, kekuatankekuatan yang dimiliki, mengetahui langkah-langkah

perbaikan apa saja yang perlu dilakukan ke depan yang berkaitan dengan posisis keuangan perusahaan saat ini, dan juga digunakan sebagai pembanding dengan perusahaan 
sejenis tentang hasil yang mereka capai. Dalam penelitian yang akan dilakukan ini, analisis rasio keuangan untuk menentukan peringkat obligasi menggunakan debt equity ratio dan current ratio.

Rasio pertama adalah Debt Equity Ratio dimana rasio ini digunakan untuk mengukur besarnya proporsi utang terhadap modal. Debt Equity Ratio (DER) yang relatif tinggi dalam sebuah perusahaan menunjukkan bahwa tingginya resiko gagal bayar untuk membayar imbalan berupa bunga dan melunasi pokok utang pada waktu yang telah ditentukan, sehingga perusahan tersebut masuk kedalam kategori obligasi yang sedikit lemah untuk berinvestasi (Low Investment Grade) dan akan menurunkan peringkat obligasi.

Rasio kedua adalah Current
$\begin{aligned} & \text { Ratio merupakan rasio yang } \\ & \text { digunakan untuk } \\ & \text { memampuan }\end{aligned}$
memenuhi kewajiban hutang jangka pendeknya yang segera jatuhtempo dengan

menggunakan aset lancar yang tersedia. Dengan kata lain, rasio lancar ini menggambarkan seberapa besar jumlah

ketersediaan aset lancar yang dimiliki perusahaan dibandingkan dengan total kewajiban lancar. Semakin tinggi nilai current ratio suatu perusahaan maka perusahaan tersebut dinilai semakin baik peringkat obligasi perusahaan.

$\begin{gathered}\text { Faktor lain } \\ \text { berpengaruh } \\ \text { adalah ung }\end{gathered}$
umur

\section{Kajian Literatur, Penelitian A. Pasar Modal}

obligasi dan ukuran perusahaan. Periode jatuh tempo obligasi bervariasi mulai dari 365 hari sampai di atas 5 tahun. Obligasi yang akan jatuh tempo dalam waktu 1 tahun akan lebih mudah untuk diprediksi sehingga

memiliki risiko yang lebih kecil dibandingkan dengan obligasi yang memiliki periode waktu jatuh tempo dalam waktu 5 tahun. Secara umum, semakin lama jatuh tempo obligasi, semakin besar tingkat ketidakpastian, sehingga semakin besar risiko maturitas.

Ukuran perusahaan (Size)

adalah rata-rata total penjualan bersih untuk tahun yang bersangkutan sampai beberapa tahun. Jika penjualan lebih besar dari biaya variabel dan biaya tetap, maka akan diperoleh jumlah pendapatan sebelum pajak. Sebaliknya jika penjualan lebih kecil dari biaya variabel dan biaya tetap maka perusahaan akan menderita kerugian. Semakin besar ukuran perusahaan, semakin kecil potensi ketidakbangkrutan.

Berdasarkan fenomena dan research gap. Dari hasil penelitian yang berbeda-beda membuat penulis tertarik untuk melakukan penelitian yang sama dengan judul "Pengaruh Debt Equity Ratio, Current Ratio, Maturity, dan Size terhadap Bond Rating (Studi pada Perusahaan Perbankan yang Terdaftar di Bursa Efek Indonesia Periode 2012-2017)". 


\begin{abstract}
Pasar modal (capital market), berhubungan dengan obligasi dan saham. Dalam pasar modal terdapat pasar perdana dan pasar sekunder. Pasar Perdana (primary market) adalah pasar untuk "penerbitan" baru. Di pasar inilah dana dikumpulkan melalui penjualan sekuritas baru, arusnya dari para pembeli sekuritas tersebut (sektor simpanan) kepada para penerbit sekuritas (sektor investasi). Pasar Sekunder (secondary market), semua sekuritas yang telah ada diperjualbelikan. Transaksi untuk sekuritas yang telah ada ini tidak memberikan tambahan dana untuk membiayai investasi modal. Pasar Modal (Capital Market) dapat didefinisikan sebagai pasar untuk berbagai instrumen

keuangan (atau sekuritas) jangka panjan yang diperjualbelikan. Dengan demikian pasar modal merupakan konsep yang lebih sempit dari pasar keuangan (financial market). Dalam pasar modal, diperdagangkan obligasi
\end{abstract} dan saham.

Berdasarkan beberapa definisi
pasar modal di atas, dapat
disimpulkan bahwa pasar modal
adalah $\quad$ pasar
memperjualbelikan instrumen keuangan baik obligasi, maupun saham. Pasar modal merupakan sumber pendanaan bagi perusahaan

$\begin{array}{ll}\text { mempertahankan } & \text { dalam } \\ \text { maupun }\end{array}$ meningkatkan kinerja perusahaan dan sarana investasi bagi investor yang memiliki kelebihan dana.

\section{B. Obligasi}

Menurut pendapat David Wijaya (2017) dalam bukunya yang berjudul Manajemen
Keuangan Konsep dan

Penerepannya, mengatakan bahwa obligasi merupakan surat utang jangka menengah atau panjang, yang dapat dipindahtangankan dan berisi janji dari pihak yang menerbitkan obligasi, untuk membayar imbalan berupa bunga atau kupon pada periode tertentu, serta melunasi pokok utang pada waktu yang telah ditentukan kepada pihak pembeli obligasi tersebut.

Obligasi adalah kontrak antara pemberi pinjaman dengan yang diberikan pinjaman. Kontrak ini diwujudkan dalam bentuk surat obligasi. Nilai obligasi adalah nilai sekarang dari arus kas yang diharapkan dari obligasi. (Sudana, 2012: 101). Obligasi (bond) adalah sekuritas yang membayarkan sejumlah bunga pada investor, setiap periode, hingga akhirnya ditarik oleh perusahaan. (James Horne dan Wachowicz, 2016: 98).

\section{Bond Rating}

Peringkat obligasi menyatakan skala risiko atau tingkat keamanan suatu obligasi yang diterbitkan serta memberikan pernyataan yang informatif dan memberikan sinyal tentang probabilitas kegagalan utang suatu perusahaan. Keamanan suatu obligasi ditunjukkan oleh kemampuan suatu perusahaan dalam membayar bunga dan melunasi pokok pinjaman sehingga pemodal mendapatkan informasi mengenai peringkat obligasi dengan menggunakan jasa agen pemeringkat obligasi tersebut. (Fauziah, 2014: 24).

$$
\text { Beberapa }
$$
lembaga pemeringkat (rating agency) yang 
ada di dunia, misalnya: Moody's Investor Service, Standar \& Poor Corporation, Duff \& Phelps, Fitch Investor Service, dan lain-lain. Sedangkan lembaga pemeringkat (rating agency) yang ada di Indonesia, seperti PT Pemeringkat Efek Indonesia (Pefindo), PT Kasnic, dan lain- lain. (Irham Fahmi, 2012: 55).

Peringkat Obligasi dibuat berdasarkan hasil penilaian terhadap credit-worthiness

perusahaan penerbit obligasi.

Pengertian creditworthiness yang dipergunakan oleh Moody's dan S\&P adalah didasarkan pada kemungkinan perusahaan gagal dan proteksi yang dimiliki kreditor jika terjadi kegagalan.

Obligasi memiliki dua peringkat yaitu investment grade (AAA, AA, A, BBB) dan noninvestment grade $(\mathrm{BB}, \mathrm{B}, \mathrm{CCC}$, dan D). Obligasi yang berperingkat $\mathrm{BBB}$ dan di atasnya dianggap obligasi bermutu investasi, sedangkan obligasi berperingkat lebih rendah digolongkan sebagai obligasi sampah (junk bond) atau bermutu spekulatif (speculative bond). Gagal bayar pada emisi berperingkat rendah sudah biasa.

\begin{tabular}{lll}
\multicolumn{2}{c}{ Berikut } & \multicolumn{2}{c}{ kategori } \\
Investment & Grade dan & Non \\
Investment Grade ditujukan pada \\
Tabel 2.1:
\end{tabular}

Tabel 2.1. Kategori Investment Grade dan Non Investment Grade

\begin{tabular}{|c|c|c|}
\hline $\begin{array}{c}\text { Perusahaa } \\
\text { n } \\
\text { Pemeringk } \\
\text { at }\end{array}$ & $\begin{array}{c}\text { Investm } \\
\text { ent } \\
\text { Grade }\end{array}$ & $\begin{array}{c}\text { Non } \\
\text { Investmen } \\
\text { t Grade }\end{array}$ \\
\hline $\begin{array}{l}\text { PT } \\
\text { Pemeringka } \\
\text { t Efek } \\
\text { Indonesia }\end{array}$ & $\begin{array}{l}\text { idAAA; } \\
\text { idAA+; } \\
\text { idAA; } \\
\text { idAA-; } \\
\text { idA+;idA } \\
\text {; idA-; } \\
\text { idBBB+; } \\
\text { idBBB; } \\
\text { idBBB- }\end{array}$ & $\begin{array}{l}\text { idBB+; } \\
\text { idBB; idBB- } \\
\text {; idB+; } \\
\text { idB;idB-; } \\
\text { idCCC; } \\
\text { idSD; idD }\end{array}$ \\
\hline
\end{tabular}

Peringkat dari idAAA sampai idB dapat dimodifikasi dengan tambahan tanda plus (+) atau minus (-) untuk menunjukkan kekuatan relatif dalam kategori peringkat. Ini disebut rating outlook.

5. Faktor-Faktor yang Memengaruhi Obligasi

Faktor-faktor yang memengaruhi peringkat obligasi menurut Bringham dan Houston. (2012:

76) adalah sebagai berikut:

a. Berbagai macam risiko rasiorasio keuangan, termasuk debt ratio, current ratio, profitability dan fixed charge coverage ratio. Semakin baik rasio-rasio keuangan tersebut semakin tinggi rating tersebut.

b. Jaminan aset untuk obligasi yang diterbitkan (mortage provision). Apabila obligasi dijamin dengan aset yang bernilai tinggi, maka rating pun akan membaik.

c. Kedudukan obligasi dengan jenis hutang lain. Apabila kedudukan obligasi lebih rendah dari utang lainnya maka rating akan ditetapkan satu tingkat lebih rendah dari yang seharusnya. 
d. Penjamin. Emiten obligasi yang lemah namun dijamin oleh perusahaan yang kuat maka emiten diberi rating yang kuat.

e. Adanya singking fund (provisi bagi emiten untuk membayar pokok pinjaman sedikit demi sedikit setiap bulan).

f. Umur obligasi. Cateris Paribus, obligasi dengan umur yang lebih pendek mempunyai risiko yang lebih kecil.

g. Stabilitas laba dan penjualan emiten.

h. Peraturan yang berkaitan dengan industri emiten.

i. Faktor-faktor lingkungan dan tanggung jawab produk.

j. Kebijakan akuntansi.

k. Penerapan kebijakan akuntansi yang konservatif mengindikasikan laporan keuangan yang lebih berkualitas.

\section{Penentu Keamanan Obligasi}

Bodie et,al. (2016:

menyatakan bahwa badan pemeringkat obligasi

mendasarkan peringkat mutunya terutama pada analisis peringkat dan tren dari beberapa rasio keuangan emiten. Rasio utama yang digunakan untuk menilai keamanan adalah: (1)
Rasio
Cakupan;
(2) Rasio

Solvabilitas;

(3) Rasio Likuiditas; (4) Rasio Profitabilitas; (5) Rasio Arus Kas terhadap Utan $6 . \quad$ Penentu Keamanan Obligasi

Bodie et,al. (2016: menyatakan bahwa badan pemeringkat obligasi

mendasarkan peringkat mutunya terutama pada analisis peringkat dan tren dari beberapa rasio keuangan emiten. Rasio utama yang digunakan untuk menilai keamanan adalah: (1) Rasio Cakupan; (2) Rasio Solvabilitas;
(3) Rasio Likuiditas; (4) Rasio Profitabilitas; (5) Rasio Arus Kas terhadap Utang

Maturity

Obligasi mempunyai periode jatuh tempo yang terbatas, yaitu tanggal saat nilai nominal obligasi harus dilunasi oleh perusahaan yang menerbitkan obligasi. Periode obligasi sangat bervariasi tergantung kebutuhan dana perusahaan, biasanya lebih dari 5 tahun. (David Wijaya, 2017: 7).

Jatuh tempo (maturity) juga dapat diartikan sebagai tanggal saat pemegang obligasi akan mendapatkan pembayaran

kembali pokok atau nilai nominal obligasi yang dimilikinya. Periode jatuh tempo obligasi bervariasi mulai dari 365 hari sampai di atas 5 tahun. Obligasi yang akan jatuh tempo dalam waktu 1 tahun akan lebih mudah untuk diprediksi sehingga memiliki risiko yang lebih kecil dibandingkan dengan obligasi yang memiliki periode waktu jatuh tempo dalam waktu 5 tahun. Secara umum, semakin lama jatuh tempo obligasi, semakin besar tingkat ketidakpastian, sehingga semakin besar risiko maturitas. (Purnomo et.al, 2014).

\section{Size}

Ukuran perusahaan

merupakan ukuran besar kecilnya sebuah perusahaan yang ditunjukan atau dinilai oleh total aset, total penjualan, jumlah laba, beban pajak dan lain-lain. (Bringham dan Houston, 2010).

Ukuran perusahaan adalah ratarata total penjualan bersih untuk tahun yang bersangkutan sampai beberapa tahun. Jika penjualan lebih besar dari biaya variabel dan biaya tetap, maka 
akan diperoleh jumlah pendapatan sebelum pajak. Sebaliknya jika penjualan lebih kecil dari biaya variabel dan biaya tetap maka perusahaan akan menderita kerugian. (Bringham dan Houston, 2014).

\section{Hubungan Antarvariabel}

Penelitian ini dilakukan untuk mengetahui pengaruh dari Debt Equity Ratio, Current Ratio, Maturity, dan Size terhadap Bond Rating.

\section{Hubungan Debt Equity Ratio terhadap Bond Rating}

Rasio ini menunjukkan berapa banyak utang perusahaan yang digunakan untuk membiayai aset relatif terhadap jumlah nilai yang dimiliki oleh ekuitas (Krantz, 2009). Debt Equity Ratio (DER) yang relatif tinggi dalam sebuah perusahaan menunjukkan bahwa tingginya resiko gagal bayar untuk membayar imbalan berupa bunga dan melunasi pokok utang pada waktu yang telah ditentukan, sehingga perusahan tersebut masuk kedalam kategori obligasi yang sedikit lemah untuk berinvestasi (Low Investment Grade) dan akan menurunkan peringkat obligasi (Dali et.al, 2015).

Penelitian sebelumnya yang ditemukan oleh Pinandhita dan Suryanti (2016), Rukmana (2016), dan Sufiyanti dan Wardani (2016) menunjukkan bahwa Debt Equity Ratio berpengaruh negatif dan signifikan terhadap peringkat obligasi.

2. Hubungan Current Ratio terhadap Bond Rating

Current Ratio merupakan rasio yang digunakan untuk mengukur kemampuan perusahaan dalam memenuhi kewajiban jangka pendeknya yang segera jatuh tempo dengan menggunakan total aset lancar yang tersedia. Semakin tinggi rasio lancar, semakin mampu perusahaan membayar

kewajibannya, karena memiliki proporsi yang lebih besar dari nilai aset relatif terhadap nilai kewajibannya. (Hery, 2017).

Penelitian yang dilakukan oleh Hanaswati dan Dirja (2008) menunjukkan bahwa Current Ratio berpengaruh positif dan signifikan terhadap peringkat obligasi. Sufiyanti dan Wardani (2016) juga menunjukkan bahwa tingkat current ratio yang tinggi akan menunjukkan kuatnya kondisi keuangan perusahaan sehingga secara finansial akan mempengaruhi prediksi peringkat obligasi.

\section{Hubungan Maturity terhadap} Bond Rating

Jatuh tempo (maturity) juga dapat diartikan sebagai tanggal saat pemegang obligasi akan mendapatkan pembayaran

kembali pokok atau nilai nominal obligasi yang dimilikinya. Periode jatuh tempo obligasi bervariasi mulai dari 365 hari sampai di atas 5 tahun. Obligasi yang akan jatuh tempo dalam waktu 1 tahun akan lebih mudah untuk diprediksi sehingga memiliki risiko yang lebih kecil dibandingkan dengan obligasi yang memiliki periode waktu jatuh tempo dalam waktu 5 tahun. Secara umum, semakin lama jatuh tempo obligasi, semakin besar tingkat ketidakpastian, sehingga semakin besar risiko maturitas. Semakin cepat jatuh tempo obligasi, semakin kecil tingkat 
ketidakpastian, sehingga semakin kecil risiko maturitas. (Purnomo et.al, 2014).

$$
\text { Penelitian sebelumnya }
$$

Hasan dan Dana (2018), Widiastuti dan Rahyuda (2016), Pinanditha dan Suryanti (2016), dan Hasnawati dan Rahmat Dirja (2008) menunjukkan hasil yaitu umur obligasi berpengaruh positif dan signifikan terhadap peringkat obligasi.

\section{Hubungan Size terhadap Bond Rating}

Ukuran perusahaan adalah ratarata total penjualan bersih untuk tahun yang bersangkutan sampai beberapa tahun. Jika penjualan lebih besar dari biaya variabel dan biaya tetap, maka akan

diperoleh jumlah

pendapatan sebelum pajak. Sebaliknya jika penjualan lebih kecil dari biaya variabel dan biaya tetap maka perusahaan akan menderita kerugian. (Bringham dan Houston, 2014).

Penelitian Rukmana (2016), Pinanditha dan Suryanti (2016), Sari dan Badjra (2016), dan Mardiyati et,al.

menunjukkan hasil serupa bahwa ukuran perusahaan berpengaruh positif dan signifikan terhadap peringkat obligasi.

5. Hubungan DER, CR, Maturity, Size terhadap Bond Rating

Banyak faktor-faktor yang mempengaruhi peringkat obligasi, yaitu berbagai macam risiko rasiorasio keuangan (debt equity ratio, current ratio, profitability, activity, dan coverage ratio), jaminan aset untuk obligasi yang diterbitkan, kedudukan obligasi dengan jenis hutang lain, penjamin emiten, adanya singking fund, umur obligasi, stabilitas laba dan penjualan emiten, peraturan yang berkaitan dengan industri emiten, faktor-faktor lingkungan dan tanggung jawab produk, dan kebijakan akuntansi. (Bringham dan Houston, 2012).

Penelitian yang dilakukan oleh Hanaswati dan Dirja (2008), dan Mardiyati et,al. (2015) menunjukkan hasil yang serupa bahwa Debt Equity Ratio, Current Ratio, Maturity, dan Size secara simultan berpengaruh positif dan signifikan terhadap Bond Rating.

\section{Hasil Penelitian Terdahulu}

Penelitian terdahulu ini menjadi salah satu dasar atau acuan dalam melakukan penelitian yang terkait dengan peringkat obligasi. Penelitian yang dilakukan oleh Hasan, dan Dana (2018) tentang pengaruh Likuiditas, dan Maturity terhadap Peringkat Obligasi tertinggi pada Sektor Keuangan di Bursa Efek Indonesia. Hasil penelitian menunjukkan bahwa (1) Likuiditas yang diukur menggunakan Current Ratio berpengaruh negatif dan signifikan terhadap Peringkat Obligasi, (2) Maturity

berpengaruh positif dan signifikan terhadap Peringkat Obligasi.

Penelitian yang dilakukan oleh Pinandhita, dan Suryanti (2016) tentang pengaruh Ukuran Perusahaan terhadap Peringkat Obligasi pada Sektor Perbankan. Hasil penelitian menunjukkan bahwa (1) Solvabilitas yang diukur menggunakan Debt Equity Ratio berpengaruh negatif signifikan terhadap Peringkat Obligasi, (2) Ukuran Perusahaan berpengaruh positif dan signifikan terhadap Peringkat Obligasi. 
Penelitian yang dilakukan oleh Mardiyati et,al. (2015) tentang The Effect Of Likuidity Toward Bond Rating On Non Financial Institution Listed In Indonesia Stock Exchange Period 2010-2014. Hasil penelitian menunjukkan (1) Likuidity yang diukur menggunakan Current Ratio berpengaruh positif tetapi tidak signifikan terhadap Bond Rating, (2) Leverage yang diukur menggunakan Debt Equity Ratio berpengaruh positif dan signifikan terhadap Bond Rating, (3) Firm Size berpengaruh positif tetapi tidak signifikan terhadap Bond Rating.

Penelitian yang dilakukan oleh Hanaswati, dan Dirja (2008) meneliti tentang pengaruh Current Ratio, Debt Equity Ratio, Size, dan Maturity terhadap Peringkat Obligasi.Hasil penelitian menunjukkan bahwa $\mathrm{CR}$, DER, Size, dan Maturity berpengaruh positif dan signifikan terhadap Peringkat Obligasi.

\section{Metode Penelitian \\ Jenis Penelitian}

Berdasarkan sifat datanya, jenis penelitian yang dilakukan adalah penelitian kuantitatif, yaitu metodologi kuantitatif sebagai prosedur penelitian yang menghasilkan data berupa angkaangka dan umumnya dianalisis dengan menggunakan statistik deskriptif atau inferensial. Metode penelitian kuantitatif digunakan untuk meneliti pada populasi atau sampel dengan menggunakan instrumen

penelitian dengan tujuan untuk menguji hipotesis yang telah dirumuskan. Statistik deskriptif adalah pengolahan dan analisis

data tanpa membuat generalisasi atau tanpa memberlakukan kesimpulan hasil penelitian secara umum. Sedangkan statistik inferensial atau induktif dengan menggunakan statistik nonparametris adalah menganalisis

data berskala ordinal dengan upaya

membuktikan hipotesis yang telah dirumuskan dengan

memberlakukan kesimpulan hasil penelitian secara umum.

Berdasarkan durasi

waktunya, jenis penelitian yang digunakan adalah cross sectional research, karena penelitian dilakukan dalam waktu relatif singkat hanya dalam semester genap 2019-2020.

Berdasarkan

pendekatan pemakaiannya, jenis penelitian yang digunakan adalah penelitian terapan. Tujuan penelitian ini adalah dipergunakan atau diimplementasikan, penelitian terapan digunakan dalam mengatasi masalah nyata mengenai Pengaruh Debt Equity Ratio, Current Ratio, Maturity, dan Size terhadap Bond Rating peneliti berusaha menemukan masalah atau kelemahan yang menjadi faktor penghambat terhadap subjek yang diteliti, kemudian mencari alternatif cara yang paling tepat dan praktis untuk mengatasinya.

\section{Definisi Operasional Variabel}

Definisi operasional adalah salah satu definisi yang diberikan kepada suatu variabel atau konstrak dengan cara memberikan arti atau melakukan spesifikasi kegiatan maupun memberikan suatu operasional yang diperlukan untuk mengukur 
konstrak atau variabel. (Sangadji

dan Sopiah, 2010).

Adapun variabel yang digunakan dalam penelitian ini adalah sebagai berikut:

\section{Bond Rating}

Obligasi yang berperingkat BBB atau di atasnya (S\&P, Fitch) atau Baa dan di atasnya (Moody) dianggap obligasi bermutu investasi (investment-grade

bonds), sedangkan obligasi berperingkat lebih rendah digolongkan sebagai obligasi sampah (junk bond) atau bermutu spekulatif (speculative bond). Gagal bayar pada emisi berperingkat rendah sudah biasa. Obligasi berperingkat tinggi jarang gagal bayar, namun obligasi ini bahkan tidak bebas dari risiko kredit (Bodie et,al. 2016).

2. Debt Equity Ratio

$$
\text { Debt Equity Ratio }
$$

merupakan rasio yang digunakan untuk mengukur besarnya proporsi utang terhadap modal (Kasmir, 2011). Debt Equity Ratio (DER) yang relatif tinggi dalam sebuah

$$
\text { perusahaan }
$$

menunjukkan bahwa tingginya resiko gagal bayar untuk membayar imbalan berupa bunga dan melunasi pokok utang pada waktu yang telah ditentukan, sehingga perusahan tersebut masuk kedalam kategori obligasi yang sedikit lemah untuk berinvestasi (Low Investment Grade) dan akan menurunkan peringkat obligasi (Dali et,al. 2015).

DER digunakan untuk mengukur rasio utang terhadap ekuitas. Rasio ini dapat dihitung hanya dengan membagi total utang perusahaan (termasuk

liabilitas jangka pendek) dengan ekuitas pemegang saham.

\section{Current Ratio}

Current Ratio merupakan rasio

yang digunakan untuk mengukur kemampuan perusahaan dalam memenuhi kewajiban jangka pendeknya yang segera jatuh tempo dengan menggunakan total aset lancar yang tersedia. Dengan kata lain, rasio lancar ini menggambarkan seberapa besar jumlah

ketersediaan asset lancar yang dimiliki perusahaan dibandingkan dengan total kewajiban lancar.

4. Maturity

Jatuh tempo (maturity) juga dapat diartikan sebagai tanggal saat pemegang obligasi akan mendapatkan pembayaran kembali pokok atau nilai nominal obligasi yang dimilikinya. Periode jatuh tempo obligasi bervariasi mulai dari 365 hari sampai di atas 5 tahun. Obligasi yang akan jatuh tempo dalam waktu 1 tahun akan lebih mudah untuk diprediksi sehingga memiliki risiko yang lebih kecil dibandingkan dengan obligasi yang memiliki periode waktu jatuh tempo dalam waktu 5 tahun. Secara umum, semakin lama jatuh tempo obligasi, semakin besar tingkat ketidakpastian, sehingga semakin besar risiko maturitas.

5. Size

Size adalah rata-rata total penjualan bersih untuk tahun yang bersangkutan sampai beberapa tahun. Jika penjualan lebih besar dari biaya variabel dan biaya tetap, maka akan diperoleh jumlah pendapatan sebelum pajak. Sebaliknya jika penjualan lebih kecil dari biaya variabel dan biaya tetap maka perusahaan akan menderita kerugian.

\section{Teknik Pengumpulan Data}

Jenis penelitian yang digunakan dalam penelitian ini adalah data sekunder eksternal yaitu perusahaanperusahaan yang terdaftar di Bursa Efek Indonesia yang menerbitkan obligasi. Sumber data dalam penelitian ini berasal dari Bursa Efek Indonesia (BEI), dan PT Pefindo.

Sesuai dengan jenis data yang 
diperlukan yaitu data sekunder dan sampel yang digunakan, maka teknik

pengumpulan data yang digunakan dengan teknik dokumen, yaitu data yang diperoleh bukan berasal langsung dari sumbernya. Data peringkat obligasi yang digunakan dalam penelitian ini diperoleh dari PT Pefindo yang menyediakan informasi peringkat obligasi perusahaan. Data untuk menghitung debt equity ratio, current ratio, maturity, dan size diperoleh dari Bursa Efek Indonesia.

\section{Populasi dan Sampel}

Populasi dalam penelitian ini adalan seluruh perusahaan sektor perbankan yang terdaftar di Bursa Efek Indonesia (BEI), yaitu sebanyak 43 perusahaan.

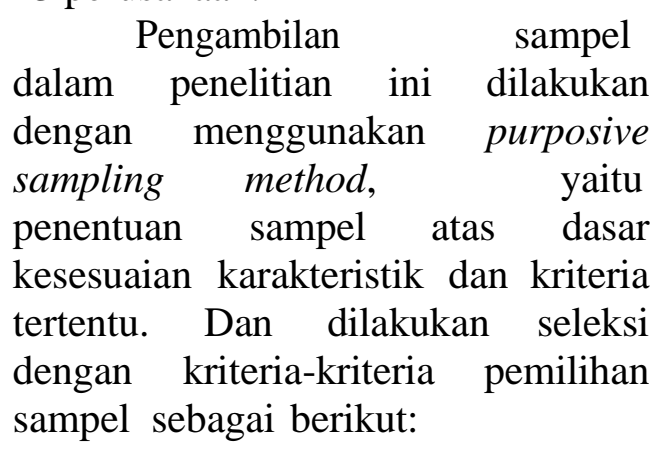

a. Jenis

perusahaan

yang dimasukkan ke dalam sampel adalah perusahaan perbankan.

b. Perusahaan listing atau terdaftar di Bursa Efek Indonesia (BEI).

C. Perusahaan listing atau terdaftar dalam peringkat obligasi yang diterbitkan oleh PT Pefindo.
d. Perusahaan mengeluarkan laporan keuangan tahunan lengkap periode 2012-2017.

Tabel 3.2. Jumlah Sampel Berdasarkan Kriteria Pemilihan Sampel

\begin{tabular}{|c|c|}
\hline Kriteria & $\begin{array}{c}\text { Jumlah } \\
\text { Perusahaan }\end{array}$ \\
\hline $\begin{array}{l}\text { Perusahaan } \\
\text { perbankan yang } \\
\text { terdaftar di } \\
\text { Bursa Efek } \\
\text { Indonesia periode } \\
\\
2017\end{array}$ & 43 \\
\hline $\begin{array}{l}\text { Perusahaan } \\
\text { perbankan } \\
\text { tersebut tidak } \\
\text { terdaftar dalam } \\
\text { peringkat obligasi } \\
\text { yang } \\
\text { diterbitkan oleh } \\
\text { PT. PEFINDO }\end{array}$ & (20) \\
\hline $\begin{array}{l}\text { Perusahaan sektor } \\
\text { perbankan yang } \\
\text { memiliki data } \\
\text { keuangan tidak } \\
\text { lengkap periode } \\
\text { 2012-2017 }\end{array}$ & (12) \\
\hline Jumlah sampel & 11 \\
\hline $\begin{array}{l}\text { Sumber: Data diolah } \\
\text { Berdasarkan } \\
\text { erdapat } 43 \text { perusal } \\
\text { yang terdaftar } \\
\text { Indonesia periode } \\
\text { berdasarkan kriteria } \\
\text { ditetapkan, maka di } \\
\text { genelitian sebanyak } \\
\text { yang }\end{array}$ & $\begin{array}{l}2020) \\
\text { abel di atas, } \\
\text { haan perbankan } \\
\text { i Bursa Efek } \\
2012-2017 \text {. Dan } \\
\text { yang telah } \\
\text { peroleh sampel } \\
11 \text { perusahaan }\end{array}$ \\
\hline
\end{tabular}


ditujukan pada Tabel 3.3 berikut ini:

Tabel 3.3.

Daftar

Sampel Penelitian

\begin{tabular}{|c|l|l|}
\hline No & Kode & \multicolumn{1}{|c|}{ Nama Perusahaan } \\
\hline 1 & BACA & Bank Capital Indonesia Tbk \\
\hline 2 & BBNI & Bank Negara Indonesia Tbk \\
\hline 3 & BBRI & $\begin{array}{l}\text { Bank Rakyat Indonesia } \\
\text { (Persero) Tbk }\end{array}$ \\
\hline 4 & BDMN & Bank Danamon Indonesia \\
\hline 5 & BGTG & PT Bank Ganesha Tbk \\
\hline 6 & BJBR & $\begin{array}{l}\text { Bank Pembangunan Daerah } \\
\text { Jawa Barat dan Banten Tbk }\end{array}$ \\
\hline 7 & BMRI & Bank Mandiri (Persero) Tbk \\
\hline 8 & BNLI & Bank Permata Tbk \\
\hline 9 & BVIC & $\begin{array}{l}\text { Bank Victoria Internasional } \\
\text { Tbk }\end{array}$ \\
\hline 10 & MEGA & Bank Mega Tbk \\
\hline 11 & SDRA & $\begin{array}{l}\text { Bank Woori } \\
\text { Indonesia 1906 Tbk }\end{array}$ \\
\hline
\end{tabular}

Teknik Analisis Data

Analisis data adalah suatu kegiatan untuk melaporkan, membuat suatu aturan,

memanipulasi, serta menyingkat

data sehingga mudah untuk dibaca dan dipahami. Dengan kata lain, kegiatan analisis data adalah data mentah yang telah dikumpulkan perlu dikategorisasikan atau dibagi atas beberapa

kategori/kelompok, dilakukan manipulasi, serta disingkat sedemikian rupa sehingga dapat menjawab masalah sesuai dengan tujuan penelitian, dan dapat menguji hipotesis.

Dalam penelitian ini digunakan metode analisis deskriptif yaitu penelitian yang bertujuan untuk menggambarkan secara terperinci suatu gejala/keadaan tertentu. Analisis ini menganalisis data dengan menggunakan data deskriptif atau pemaparan data yang diperoleh dari Perusahaan Perbankan yang terdaftar di Bursa Efek Indonesia.

Selanjutnya data yang terkumpul akan dianalisis yang logis berkaitan dengan hubungan kualitas variabel yang diteliti. Analisis dilakukan melalui perhitunganperhitungan dengan menggunakan rumus sebagai berikut:

\section{Pengukuran Rasio Keuangan}

a. Rasio Utang atas Modal (Debt to Equity Ratio)

merupakan rasio yang digunakan untuk menilai utang dengan ekuitas. Rasio ini berguna untuk mengetahui jumlah dana yang disediakan peminjam (kreditor) dengan pemilik perusahaan.

\section{b. Rasio Lancar (Current Ratio)}

merupakan rasio yang digunakan untuk mengukur kemampuan perusahaan dalam memenuhi kewajiban jangka pendeknya yang segera jatuh tempo dengan menggunakan total aset lancar yang tersedia.

Current Ratio (CR) =

$$
\mathrm{x} 100 \%
$$

\section{Analisis Statistik Deskriptif}


Analisis statistik deskriptif adalah statistik yang digunakan untuk analisa data dengan cara mendeskripsikan atau menggambarkan data yang telah terkumpul sebagaimana adanya tanpa ada tujuan membuat kesimpulan untuk generalisasi.

Analisis deskriptif digunakan untuk menggambarkan atau mendeskripsikan data terkait penelitian yang telah dikumpulkan dilihat dari nilai ratarata, standar deviasi, maksimum, dan minimum. Dengan demikian, analisis ini berguna untuk memberi gambaran tentang bond rating, debt equity ratio, current ratio, maturity, dan size dilihat dari nilai rata-rata, standar deviasi, maksimum, dan minimum.

\section{Uji Regresi Logistik}

Analisis yang digunakan dalam penelitian ini adalah analisis regresi logistik/logit (logistic regretion). Analisis regresi logistik digunakan untuk menjelaskan hubungan antara variabel respon yang berupa data dikotomik/biner dengan variabel bebas yang berupa data berskala interval dan atau kategorik (Hosmer dan Lemeshow, 1989). Dalam penelitian ini, analisis yang digunakan adalah analisis regresi logistik biner, karena variabel terikat merupakan variabel dikotomi yang mempunyai dua kategori saja, yaitu peringkat obligasi dengan kategori investment dan non invesment grade.

Model statistik ini sesuai dengan penelitian ini karena variabel dependennya adalah variabel dummy yaitu investment grade dan non investment grade. Data kemudian dikumpulkan dan diolah serta dianalisis untuk pengujian hipotesis dengan langkahlangkah yang akan dibahas setelah ini.

\section{a. Menilai Model Fit dan \\ Keseluruhan (Overall Model Fit)}

Uji ini digunakan untuk menilai model yang telah dihipotesiskan telah fit atau tidak dengan data. Hipotesis untuk menilai model fit adalah:

$\mathrm{H}_{0}$ : Model yang dihipotesiskan fit dengan data

$\mathrm{H}_{1}$ : Model yang dihipotesiskan tidak fit dengan data

Agar model fit dengan data,

maka $\mathrm{H}_{0}$ harus diterima.

Likelihood (L) dari model adalah probabilitas bahwa model yang dihipotesiskan menggambarkan data input. Untuk menguji hipotesis nol dan hipotesis alternatif, L ditransformasikan menjadi -2LogL.

Dengan $\alpha=5 \%$, cara menilai model fit ini adalah sebagai berikut:

1) Jika nilai $-2 \log \mathrm{L}<0,05$ berarti model fit dengan data.

2) Jika nilai $-2 \log \mathrm{L}>$ 0,05 berarti model tidak fit dengan data.

Adanya pengurangan nilai antara -2LogL awal (initial -2LL funtcion) dengan nilai -2LogL pada langkah berikutnya menunjukkan bahwa model yang dihipotesiskan fit dengan data (Ghozali, 2005). Log Likelihood pada regresi logistik mirip dengan pengertian "Sum of Square Error" pada model regresi, sehingga 
penurunan Log Likelihood menunjukkan model regresi yang semakin baik.

\section{b. Menilai Kelayakan Model Regresi (Goodness of Fit Test)}

Kelayakan model regresi dinilai dengan menggunakan Hosmer and Lemeshow's Goodness of Fit Test. Dasar pengambilan keputusan untuk menilai kelayakan model menurut Ghozali (2011) adalah nilai Hosmer and Lameshow's Goodness of Fit Test yang diukur dengan nilai chisquare harus menunjukkan angka lebih besar dari 0,05. Artinya, hipotesis nol tidak dapat ditolak sehingga tidak ada perbedaan antara model dengan data yang diamati karena model mampu memprediksi nilai observasinya atau dapat

dikatakan model dapat diterima.

\section{Uji Hipotesis}

a. Koefisien Determinasi (Nagelkerke's R square)

Nagelkerke $R \quad$ Square merupakan pengujian yang dilakukan untuk mengetahui seberapa besar variabel independen maupu menjelaskan dan mempengaruhi variabel dependen. Nilai Nagelkerke $R$ Square bervariasi antara 1 (satu) sampai dengan 0 (nol). Jika nilai semakin mendekati 1 maka model dianggap semakin goodness of fit, sementara jika semakin mendekati 0 maka model dianggap tidak goodness of fit (Ghozali, 2011: 277).

\section{b. Matriks Klasifikasi}

Matriks klasifikasi bertujuan untuk memprediksi model regresi untuk memprediksi apakah perusahaan menerima opini going concern atau tidak. Menurut Ghozali (2011: 338) menyatakan bahwa matriks klasifikasi menghitung nilai estimasi yang benar (correct) dan (incorrect).

Pada bagian kolom dalam matriks terdapat nilai prediksi berdasarkan peringkat obligasi yang dibuat, yaitu obligasi dengan investment grade (1) dan non investment grade (0). Pada bagian baris baris akan menunjukan nilai observasi

pengaruh variabel independen terhadap variabel dependen. Pada model yang dikategorikan matriks yang sempurna, jika semua kasus berada pada diagonal dengan tingkat

ketepatan peramalan $100 \%$.

\section{c. Estimasi Parameter dan Interpretasi Individual}

Estimasi parameter dapat
dilihat melalui koefisien regresi. Koefisien regresi dari tiap-tiap variabel yang diuji menunjukkan bentuk hubungan antara variabel. Pengujian hipotesis dilakukan dengan cara membandingkan antara nilai probabilitas (sig) dengan tingkat signifikansi $(\alpha)$ sebesar 0,05. Jika variabel dependen dan independen tidak signifikan terhadap probabilitas (sig) lebih besar dari 0,05 maka artinya variabel independen tidak memiliki pengaruh terhadap variabel dependen. Sebaliknya, jika probabilitas (sig) lebih kecil dari 0,05 , maka variabel 
independen memiliki pengaruh terhadap variabel dependen.

Model atau rumus regresi logistik yang digunakan dalam penelitian ini adalah sebagai berikut:

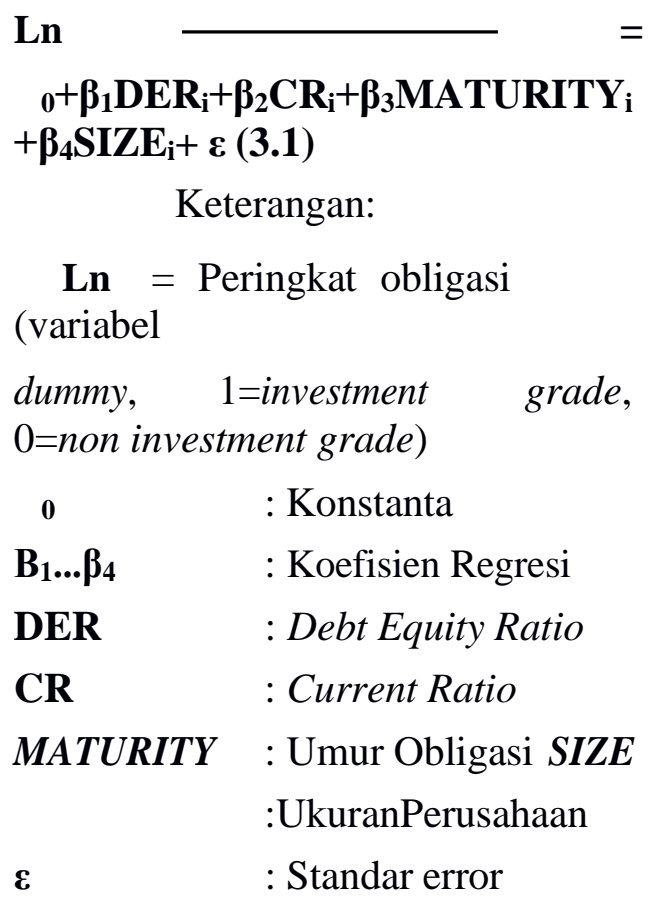

\section{d. Pengujian Simultan}

Tujuan dilakukan pengujian simultan adalah untuk melihat secara bersama pengaruh variabel-variabel independen

(DER, CR, maturity dan firm size) terhadap variabel dependen yaitu peringkat obligasi. Pengujian simultan pada regresi logistik ditunjukkan dengan nilai Omnibus Test of Model Coefficients.

\section{Dasar pengambilan} keputusan dalam pengujian ini adalah sebagai berikut:

a. Jika nilai probabilitas (sig) lebih tinggi dari tingkat signifikansi $(\alpha) 0,05$ atau $5 \%$. Maka dapat dikatakan secara bersama-sama variabel independen tidak mempengaruhi variabel dependen.

b. Jika nilai probabilitas (sig) lebih kecil dari tingkat signifikansi $(\alpha) 0,05$ atau $5 \%$. Maka dapat dikatakan secara bersama-sama variabel independen mempengaruhi variabel dependen.

\section{Hasil dan Pembahasan Objek Penelitian}

Bond Rating (peringkat obligasi) adalah "tingkat" yang ditetapkan untuk obligasi. Peringkat ini juga dapat diberikan kepada penerbit obligasi, perusahaan asuransi, atau entitas lain atau sekuritas untuk menunjukkan keberisikoan.

Peringkat obligasi memiliki pengaruh besar pada harga dan permintaan untuk obligasi tertentu. Semakin rendah peringkat, semakin berisiko investasi dan semakin sedikit nilai investasi. Peringkat obligasi yang rendah sering menyebabkan aktivitas perdagangan yang kurang dan dengan demikian masalah likuiditas. Inilah sebabnya mengapa penurunan (atau desas-desus penurunan peringkat) dalam peringkat kredit emiten dapat memiliki dampak signifikan pada obligasi dan di pasar atau industri.

Obligasi

diperdagangkan sebelum harus diperingkat terlebih dahulu oleh lembaga pemeringkat efek. Di Indonesia lembaga yang menentukan peringkat obligasi adalah PT Pefindo. Fungsinya yaitu untuk memberikan peringkat yang objektif, independen, dan dapat dipercaya terhadap risiko kredit sekuritas utang secara publik. PT Pefindo melakukan penilaian obligasi berdasarkan 
risiko industri, risiko bisnis dan risiko keuangan perusahaan. Sumber informasi utama yang digunakan oleh Pefindo dalam menetapkan peringkat obligasi adalah laporan keuangan perusahaan penerbit obligasi

Perusahaan-perusahaan yang termasuk dalam sub sektor perbankan yang memenuhi kriteria adalah sebanyak 11 perusahaan yang listed di Bursa Efek Indonesia dan obligasinya diperingkat oleh PT. Pefindo periode 2012-2017. Dalam kriteria tersebut, dapat ditentukan DER, CR, Maturity dan Size yang akan diuji terhadap peringkat obligasinya. Berikut adalah sampel perusahaan yang akan diuji ditujukan pada Tabel $4.1 \mathrm{di}$ bawah ini: Tabel 4.1.Sampel

\section{Penelitian}

\begin{tabular}{|c|c|l|}
\hline No & Kode & Nama Perusahaan \\
\hline 1 & BACA & $\begin{array}{l}\text { Bank Capital } \\
\text { Indonesia Tbk }\end{array}$ \\
\hline 2 & BBNI & $\begin{array}{l}\text { Bank Negara } \\
\text { Indonesia Tbk }\end{array}$ \\
\hline 3 & BBRI & $\begin{array}{l}\text { Bank Rakyat } \\
\text { Indonesia (Persero) } \\
\text { Tbk }\end{array}$ \\
\hline 4 & BDMN & $\begin{array}{l}\text { Bank Danamon } \\
\text { Indonesia }\end{array}$ \\
\hline 5 & BGTG & $\begin{array}{l}\text { PT Bank Ganesha } \\
\text { Tbk }\end{array}$ \\
\hline 6 & BJBR & $\begin{array}{l}\text { Bank Pembangunan } \\
\text { Daerah Jawa Barat } \\
\text { dan Banten Tbk }\end{array}$ \\
\hline 7 & BMRI & $\begin{array}{l}\text { Bank Mandiri } \\
\text { (Persero) Tbk }\end{array}$ \\
\hline 8 & BNLI & Bank Permata Tbk \\
\hline 9 & BVIC & $\begin{array}{l}\text { Bank Victoria } \\
\text { Internasional Tbk }\end{array}$ \\
\hline 10 & MEGA & Bank Mega Tbk \\
\hline 11 & SDRA & $\begin{array}{l}\text { Bank Woori Saudara } \\
\text { Indonesia 1906 Tbk }\end{array}$ \\
\hline
\end{tabular}

\section{Analisis Deskriptif}

Analisis deskriptif adalah bagian dari statistik yang digunakan manggambarkan untuk bermaksud menggenaralisir atau membuat kesimpulan tapi hanya menjelaskan kelompok data.

Analisis statistik yang digunakan dalam penelitian ini terdiri dari $\mathrm{N}$ adalah jumlah data, nilai minimum dan maksimum, nilai mean, dan standar deviasi. Secara ringkas hasil analisis statistik deskriptif disaikan dalam Tabel 4.2 di bawah ini:

\section{Descriptive Statistics}

\begin{tabular}{|c|c|c|c|c|c|}
\hline & $\mathrm{N}$ & $\begin{array}{l}\text { Mini } \\
\text { mum }\end{array}$ & $\begin{array}{c}\text { Maxim } \\
\text { um }\end{array}$ & Mean & $\begin{array}{c}\text { Std. } \\
\text { Deviati } \\
\text { on } \\
\end{array}$ \\
\hline $\begin{array}{l}\text { Bond } \\
\text { Rati } \\
\text { ng }\end{array}$ & 66 & 0 & 1 & .80 & .401 \\
\hline DER & 66 & $\begin{array}{r}2.775 \\
4 \\
\end{array}$ & $\begin{array}{r}13.168 \\
4 \\
\end{array}$ & $\begin{array}{r}7.2000 \\
04 \\
\end{array}$ & $\begin{array}{r}2.4104 \\
512\end{array}$ \\
\hline CR & 66 & .0053 & 3.9300 & $\begin{array}{r}.85697 \\
6 \\
\end{array}$ & $\begin{array}{r}.78839 \\
89 \\
\end{array}$ \\
\hline $\begin{array}{l}\text { Matu } \\
\text { rity }\end{array}$ & 66 & 0 & 1 & .55 & .502 \\
\hline SIZE & 66 & 14 & 21 & 18.17 & 1.894 \\
\hline $\begin{array}{l}\text { Valid } \\
\mathrm{N} \\
\text { (listw } \\
\text { ise) }\end{array}$ & 66 & & & & \\
\hline $\begin{array}{l}\text { I } \\
\text { menunju } \\
\text { pengam } \\
\text { perbank } \\
\text { Efek Ir } \\
\text { dalam p } \\
\text { Bond } \\
\text { depende }\end{array}$ & $\begin{array}{l}\text { Serda } \\
\text { kkan } \\
\text { atan } \\
\text { an ya } \\
\text { ddone } \\
\text { enelit } \\
\text { Rati }\end{array}$ & $\begin{array}{l}\text { arkan } \\
\text { ba } \\
\text { pada } \\
\text { ang terd } \\
\text { sia peri } \\
\text { lan ini s } \\
\text { ng ac } \\
\text { lam pe }\end{array}$ & \begin{tabular}{l}
\multicolumn{2}{c}{ tabel } \\
hwa \\
daftar di per \\
iode 201 \\
sebanyak \\
dalah v \\
enelitian
\end{tabular} & $\begin{array}{l}\text { diatas } \\
\text { jumlah } \\
\text { usahaan } \\
\text { i Bursa } \\
12-2017 \\
66 \text { data. } \\
\text { ariabel } \\
\text { ini }\end{array}$ & \\
\hline
\end{tabular}


dengan nilai adalah dummy, yaitu investment grade dan non investment grade. Dari hasil uji statistik deskriptif, menunjukan bahwa nilai terkecil adalah 0 dan terbesar adalah 1. Kategori investment grade memiliki peringkat yang baik maka akan dipercaya oleh investor karena diharapkan dapat memberikan tingkat pengembalian yang sesuai dengan harapan investor. Nilai mean Bond Rating adalah sebesar 0,80, dengan standar deviasi sebesar 0,401. Artinya, selama periode pengamatan, peringkat obligasi berfluktuasi rendah di tiap tahunnya, karena standar deviasi yang dihasilkan lebih rendah dari mean.

Nilai Debt Equity Ratio (DER) terendah (minimum) diperoleh Bank Woori Saudara Indonesia 1906 Tbk periode 2013 sebesar 2,7754, dan nilai tertinggi (maksimum) juga diperoleh Bank Woori Saudara Indonesia 1906 Tbk periode 2012 yaitu sebesar 13,1684. Selain itu, nilai DER menunjukkan angka mean sebesar 7,200004, dengan nilai standar deviasi sebesar 2,4104512. Hal ini menunjukkan bahwa data pada variabel Debt Equity Ratio memiliki sebaran yang kecil, karena standar deviasi DER mempunyai hasil yang lebih kecil dari mean yang dihasilkan. Dengan demikian, dapat disimpulkan bahwa data variabel Debt to Equity Ratio (DER) merupakan data yang mempunyai sebaran yang baik.

Nilai Curret Ratio (CR) terendah (minimum) diperoleh Bank Mega Tbk periode 2017 yaitu sebesar 0,0053 dan nilai tertinggi (maksimum) diperoleh Bank
Victoria International Tbk periode 2015 yaitu sebesar 3,9300. Selain itu, CR menunjukkan nilai mean sebesar 0,856976 dengan nilai standar deviasi sebesar 0,7883989. Hal ini menunjukkan bahwa data pada variabel Current Ratio memiliki sebaran yang kecil, karena standar deviasi $\mathrm{CR}$ mempunyai hasil yang lebih kecil dari mean yang dihasilkan. Dengan demikian, dapat disimpulkan bahwa data variabel Current Ratio (CR) merupakan data sebaran yang baik. yang mempunyai

Nilai Maturity terendah (minimum) adalah 0 (artinya jatuh tempo obligasi tersebut 1-5 tahun) sedangkan nilai tertinggi (maksimum) adalah 1 (artinya jatuh tempo obligasi tersebut 5-

12 tahun). Secara umum, semakin lama jatuh tempo obligasi, semakin besar tingkat ketidakpastian, sehingga semakin besar risiko maturitas

Nilai Size dalam penelitian ini dihitung dengan menggunakan logaritma natural dari total aktiva perusahaan. Hasil statistik deskriptif ukuran perusahaan menunjukkan bahwa logaritma natural minimum yang didapat adalah 14 diperoleh PT Bank Ganesha Tbk periode 20122017. Sedangkan logaritma natural maksimum yang didapat adalah sebesar 21 diperoleh Bank Mandiri Tbk periode 2014-2017. Selain itu, Size menunjukkan nilai mean sebesar 18,17 dengan nilai standar deviasi sebesar 1,894. Hal ini menunjukkan bahwa data pada variabel Size memiliki sebaran yang kecil, karena standar deviasi Size mempunyai hasil yang lebih kecil dari mean 
Jurnal Manajemen dan Bisnis, Volume 1, No. 2, Januari 2020

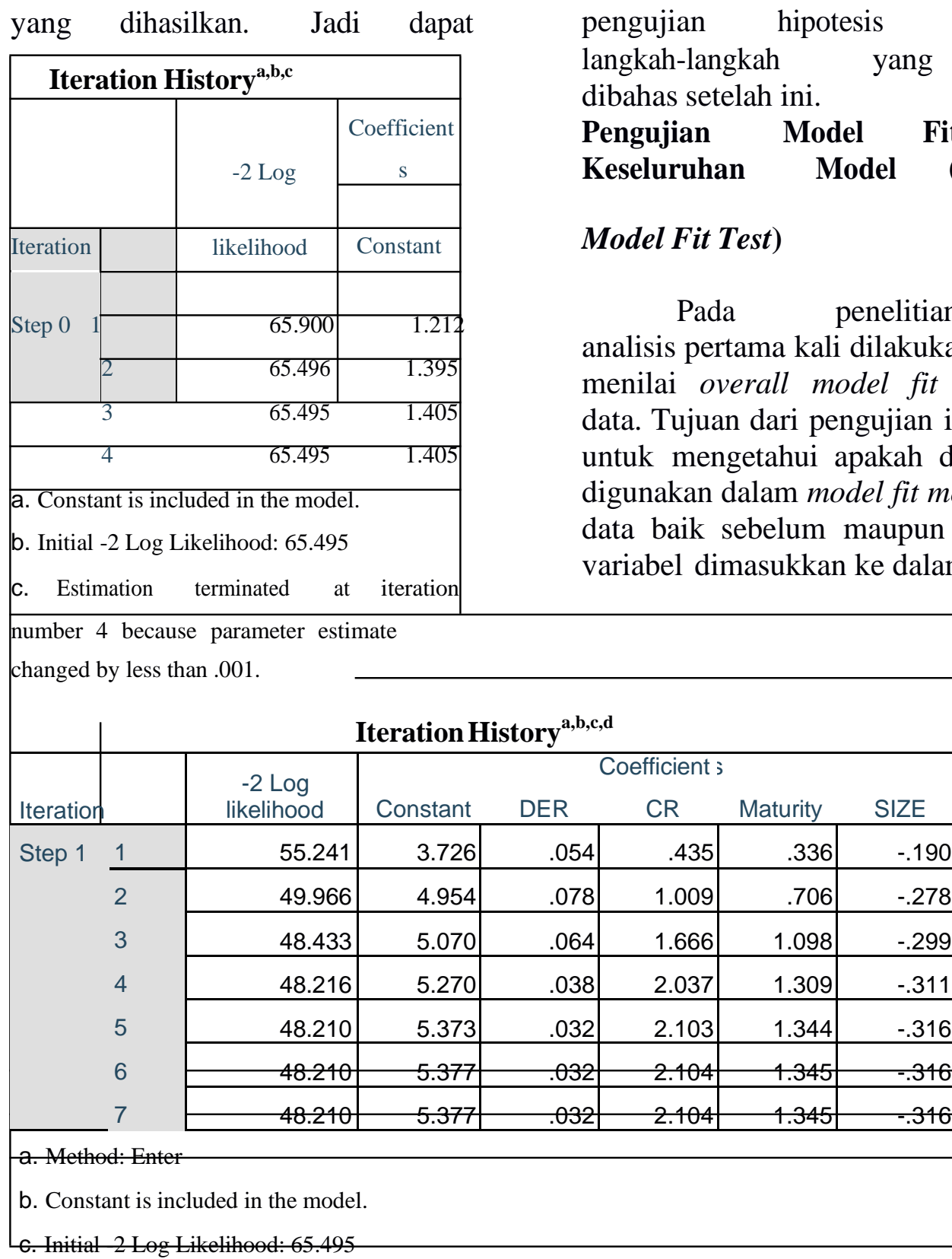

Adap un esis untu menil

d. Estimation terminated at iteration number 7 because parameter el fit

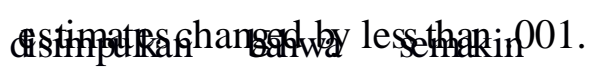

besar total aktiva suatu perusahaan, maka ukuran perusahaan tersebut semakin besar.

\section{Uji Regresi Logistik}

Model statistik ini sesuai dengan penelitian ini karena variabel dependennya adalah variabel dummy yaitu investment grade dan non investment grade. Data kemudian adalah sebagai berikut:

dikumpulkan dan diolah serta 
Jurnal Manajemen dan Bisnis, Volume 1, No. 2, Januari 2020

$\mathrm{H}_{0}$ : Model yang dihipotesiskan fit dengan data

$\mathrm{H}_{1}$ : Model yang dihipotesiskan tidak fit dengan data

Tabel 4.4.

\section{Iteration History Kedua}

Keseluruhan model dinilai dengan membandingkan antara 2LogL pada awal (block number $=0$ ) dengan nilai -2LogL pada akhir (block number=1). Nilai 
-2LogL pada awal adalah sebesar 65,900 dan setelah memasukkan empat variabel independen yaitu DER, CR, Maturity dan Size pada akhir nilai -2LogL mengalami penurunan menjadi 48,210. Hal ini menunjukkan penurunan nilai - 2LogL di block number 0 dan block number 1 sebesar 17,690 . Penurunan angka ini dapat diartikan bahwa penambahan variabel bebas ke dalam model dapat memperbaiki model fit serta menunjukkan model regresi yang lebih baik atau dengan kata lain $\mathrm{H}_{0}$ diterima, $\mathrm{H}_{1}$ ditolak dan model fit dengan data. Dengan kata lain, penurunan nilai $-2 \log \mathrm{L}$ menunjukkan model regresi yang baik atau dengan kata lain model yang dihipotesiskan cocok dengan data.

\section{Menilai Kelayakan Model Regresi (Goodness of Fit Test)}

Analisis selanjutnya yang digunakan adalah menilai kelayakan model regresi logistik yang akan digunakan adalah goodness of fit test yang diukur dengan Chi-Square pada bagian bawah uji Hosmer dan Lemeshow. Probabilitas signifikansi yang diperoleh kemudian dibandingkan dengan tingkat signifikansi $(\alpha) 5$

$\%$. Hipotesis yang digunakan untuk menilai kelayakan model regresi adalah:

HO : Tidak ada perbedaan antara model dengan data

Hasil pengujian goodness of fit test dapat dilihat pada tabel 4.5. sebagai berikut:

\section{Tabel 4.5. Hosmer and}

\section{LemeshowTest}

\begin{tabular}{|l|r|r|r|}
\hline \multicolumn{4}{|c|}{ Hosmer and Lemeshow Test } \\
\hline Step & Chi-square & \multicolumn{1}{c|}{ df } & Sig. \\
\hline 1 & 3.019 & 7 & .883 \\
\cline { 2 - 4 }
\end{tabular}

Sumber : Data Diolah (2020)

Hasil pengujian Hosmer and Lemeshow Test sebesar 3,019 ditunjukkan pada tabel di atas dengan probabilitas signifikansi yang menunjukkan angka 0,883. Nilai signifikansi yang diperoleh jauh lebih besar dari pada $0,05(\alpha) 5 \%$, maka $\mathrm{H} 0$ diterima dan $\mathrm{H} 1$ ditolak. Hal ini berarti model regresi layak digunakan dalam analisis selanjutnya dan mampu memprediksi nilai observasinya. Dengan kata lain, model dapat diterima karena cocok dengan data observasinya.

\section{Hasil Pengujian Hipotesis}

Pengujian hipotesis dalam penelitian ini adalah dengan menggunakan model regresi logistik. Regresi logistik adalah regresi yang digunakan untuk menguji apakah probabilitas terjadinya variabel dependen dapat diprediksi oleh variabel independen. Model regresi logistik digunakan untuk menguji pengaruh peringkat obligasi terhadap rasio-rasio keuangan yang diantaranya yaitu DER, CR, Maturity dan Size. Pengujian dilakukan dengan tingkat signifikansi $(\alpha) 5 \%$ dan $(\alpha)$ $10 \%$. Teknik ini tidak lagi memerlukan uji normalitas, heteroskedastisitas, dan uji asumsi klasik lainnya pada variabel bebasnya. Karena uji asumsi klasik digunakan untuk analisis regresi berganda. 


\section{Koefisien Determinasi (R2)}

Koefisien determinasi

digunakan untuk mengetahui seberapa besar variabilitas variabel independen mampu memperjelas variabel dependen. Koefisien determinasi pada regresi logistik ini dapat dilihat pada nilai Nagelkerke $\mathrm{R}$ Square. Nilai tersebut dapat diinterpretasikan seperti R2 pada multiple regression. Nilai ini didapat dengan cara membagi Cox \& Sneel R Square dengan nilai maksimumnya. Berdasarkan pengolahan data sekunder melalui program SPSS 25.0 diperoleh hasil koefisien determinasi pada tabel 4.6. sebagai berikut:

\begin{tabular}{|l|c|c|c|}
\hline \multicolumn{4}{|c|}{ Model Summary } \\
\hline & & Cox \& & \\
Step & likelihood & Square & R Square \\
\hline 1 & $48.210^{\mathrm{a}}$ & .230 & .366 \\
\hline \multicolumn{4}{|c|}{} \\
a. Estimation terminated at iteration number 7 \\
because parameter estimates changed by less than \\
.001.
\end{tabular}

\section{Tabel 4.6. $\quad$ Nagelkerke $R$ Square}

Sumber : Data Diolah (2020)

Dari tabel di atas, dapat dilihat hasil output pengolahan data nilai Nagelkerke $\mathrm{R}$ Square adalah sebesar 0,366 yang berarti variabilitas variabel dependen yang dapat dijelaskan oleh variabel dependen adalah sebesar 36,6\%. Hal ini berarti bahwa variabel bebas dapat menjelaskan variasi variabel peringkat obligasi sebesar 36,6 $\%$, atau dengan kata lain DER, CR, Maturity dan Size dapat memengaruhi peringkat obligasi sebesar $36.6 \%$. Sedangkan sisanya sebesar 63,4 \% merupakan kontribusi dari faktor lain seperti ROA, ROE, QR, dan lain-lain yang tidak diteliti dalam penelitian ini.

\section{Matrik Klasifikasi}

Matrik klasifikasi akan menunjukkan kekuatan prediksi dari model regresi untuk memprediksi

\section{kemungkinan}

peringkat obligasi pada perusahaan. Hasil pengujian matrik klasifikasi dapat ditunjukkan pada tabel 4.7. di bawah ini:

\section{Tabel 4.7. Classification Table}

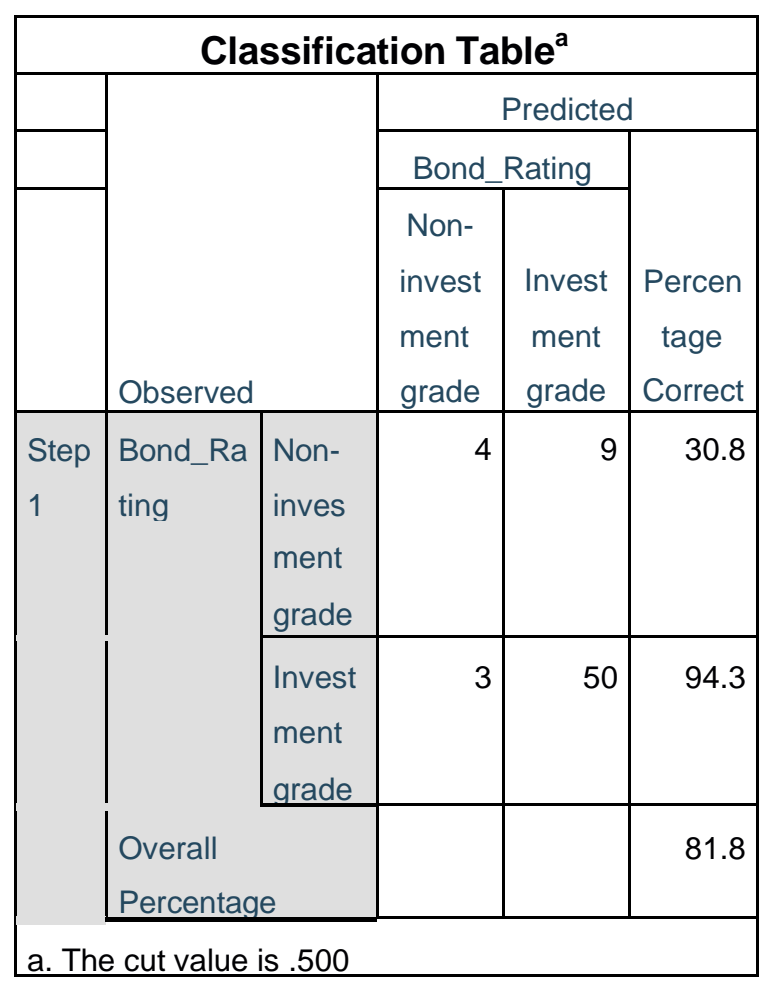

Dari hasil pengujian dapat diketahui bahwa menurut prediksi, data yang masuk ke dalam kategori investment grade adalah sebanyak 53 sedangkan observasi sesungguhnya menunjukkan bahwa data yang berkategori investment grade adalah sebanyak 50. Jadi 
ketepatan model ini adalah 50/53 atau $94,34 \%$. Artinya sebesar 94,34\% perusahaan perbankan yang terdaftar di BEI periode 2012-2017 termasukdalam kategori investment grade. Menurut prediksi, data yang masuk ke dalam kategori non investment grade adalah sebanyak 13, sedangkan observasi sesu I

menunjukkan bahwa

berkategori non investm adalah 4. Jadi ketepat ini; adalah 4/13 atau berarti : sebesar $\quad 3$

perusahaan perban terdaftar di BEI perio ( 2017 termasuk dalam non investment

Sedangkan ketepatan keseluruhan model i $81,8 \%$.

\section{Estimasi Parameter dan Interpretasi Individual}

Estimasi parameter dapat dilihat melalui koefisien regresi. Koefisien regresi dari tiap-tiap variabel yang diuji menunjukkan hubungan antara variabel. Pengujian hipotesis dalam penelitian ini untuk menguji pengaruh variabel bebas yaitu DER, CR, Maturity dan Size terhadap Bond Rating dengan menggunakan hasil uji regresi yang ditunjukkan dalam tabel Variables in the Equation.

Dalam uji hipotesis dengan regresi logistik, dapat cukup dilihat di bagian Variables in the Equation pada kolom significant dengan tingkat kealphaan $0,05(5$

$\%)$ dan 0,10 (10\%). Apabila tingkat signifikansi $<0,05$, maka hipotesis diterima. Dan jika tingkat signifikansi > 0,05, maka hipotesis ditolak.

Kemudian apabila tingkat signifikansi $<0,10$, maka hipotesis diterima. Dan jika tingkat signifikansi > 0,10, maka hipotesis ditolak pengujian hipotesis secara parsial dapat dilihat pada tabel 4.8. di bawah ini:

Tabel 4.8. Variables in the Equation

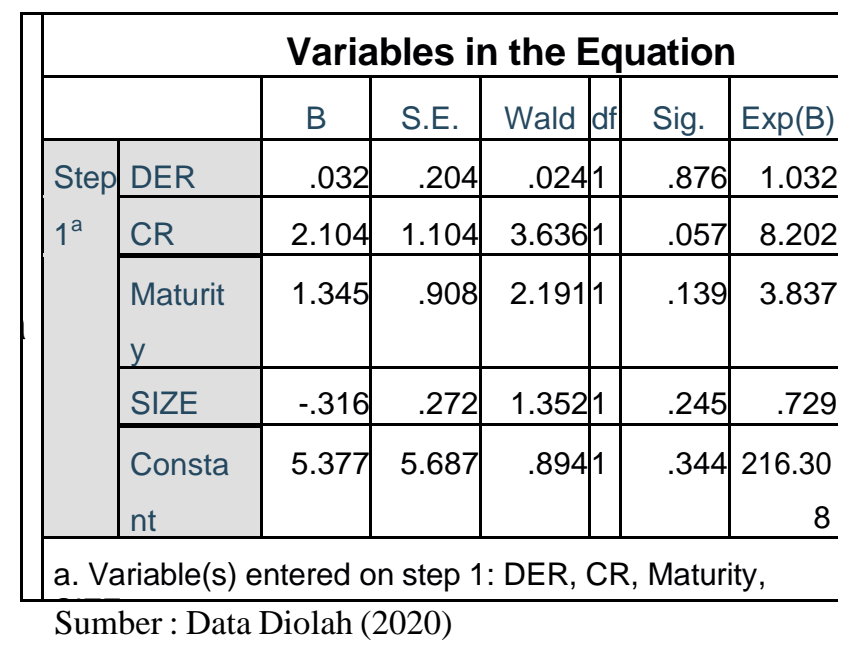

Hasil pengujian menunjukkan pada regresi logistik pada tingkat signifikansi $5 \%$ dan paling besar $10 \%$. Dari pengujian dengan regresi logistik di atas maka dapat diperoleh persamaan regresi logistik sebagai berikut:

$\mathrm{Ln}-\quad=5,377+$

0,032DER + 2,104CR + 1,345 MATURITY $-0,316$ SIZE $+\varepsilon$

Keterangan:

$\mathrm{CR}=$ Current Ratio.

DER = Debt to Equity Ratio.

MATURITY = Umur Obligasi.

$S I Z E=$ Ukuran Perusahaan. $\varepsilon=$ error.

Berdasarkan hasil dari regresi tersebut, dapat diinterpretasikan beberapa hal sebagai berikut:

a. Nilai konstanta untuk persamaan regresi yaitu 5,377 dengan tingkat signifikansi 0,344 yang 
lebih besar dari pada 0,05 (5 $\%)$. Hal ini menunjukkan bahwa jika DER, CR, Maturity dan Size tidak terjadi perubahan atau constant, maka Bond Rating pada perusahaan perbankan yang terdaftar di BEI periode 20122017 adalah sebesar 5,277.

b. Koefisien Debt to Equity Ratio bernilai positif yaitu 0,032 dengan tingkat signifikansi 0,876 yang lebih besar dari 0,05 (5\%). Hal ini menunjukkan bahwa setiap ada peningkatan DER, maka peringkat obligasi akan mengalami peningkatan. Sebaliknya, setiap ada penurunan DER, maka peringkat obligasi akan mengalami penurunan. Karena nilai signifikansi lebih besar dari $0,05(5 \%)$ yaitu sebesar 0,876 , maka

hipotesis 1 dalam pennelitian variaineil Debitolak Equity Ratio tidak berpengaruh signifikan terhadap Bond Rating. Apabila terjadi peningkatan sebesar 1 pada DER, maka Bond Rating akan meningkat sebesar 0,032 .

c. Koefisien Current Ratio (CR) bernilai positif yaitu 2,104 dengan tingkat signifikansi 0,057 yang lebih kecil dari 0,05 (5\%). Hal ini menujukkan bahwa setiap ada peningkatan CR, maka peringkat obligasi akan mengalami peningkatan. Sebaliknya, setiap ada penurunan CR, maka peringkat obligasi akan mengalami

penurunan. Karena nilai signifikansi lebih kecil dari $0,05(5 \%)$ yaitu sebesar 0,057 , maka hipotesis 2 dalam penelitian ini diterima, yaitu Current Ratio berpengaruh positif dan signifikan terhadap Bond Rating. Apabila terjadi peningkatan

sebesar 1 pada CR, maka Bond Rating akan meningkat sebesar 2,104.

d. Koefisien Maturity bernilai positif yaitu 1,345 dengan tingkat signifikansi 0,139 yang berarti lebih besar dari 0,05 (5 \%). Hal ini menunjukkan bahwa setiap ada penurunan variabel Maturity, maka peringkat obligasi mengalami penurunan. Sebaliknya, setiap ada kenaikan Maturity, maka peringkat obligasi mengalami kenaikan pula. Karena nilai signifikansi lebih kecil dari 0,05 (5\%) yaitu sebesar 0,139 , maka hipotesis 3 dalam penelitian ini ditolak. Sehingga variabel Maturity tidak berpengaruh signifikan terhadap Bond Rating. Apabila terjadi penurunan sebesar 1 pada Maturity, maka Bond Rating akan meningkat sebesar 1,345.

e. Koefisien Size bernilai negatif yaitu -0,316 dengan tingkat signifikansi 0,245 yang berarti lebih besar dari tingkat 
signifikansi $0,10(10 \%)$. Hal ini menunjukkan bahwa setiap ada penurunan Size, maka peringkat obligasi akan mengalami kenaikan. Sebaliknya, setiap ada kenaikan Size, maka peringkat obligasi akan mengalami penurunan. Karena nilai signifikansi lebih besar dari $0,10(10$

$\%)$ yaitu sebesar 0,245, maka hipotesis 4 dalam penelitian ini ditolak, yaitu Size berpengaruh negatif dan tidak signifikan terhadap Bond Rating. Apabila terjadi penurunan sebesar 1 satuan pada Size, maka Bond Rating akan naik sebesar 0,316 .

\section{Pengujian Simultan}

Pengujian simultan dalam model regresi logistik ditunjukkan dengan nilai Omnibus Test of Model Coefficients. Omnibus Test of Model Coefficients merupakan analisis yang digunakan untuk menguji pengaruh secara simultan (bersama-sama) antara variabel independen terhadap variabel dependen. Jika nilai signifikansi kurang dari 0,05, maka variabel independen berpengaruh terhadap variabel dependen secara bersamasama. Hasil pengujian simultan dapat dilihat pada Tabel 4.9. sebagai berikut:

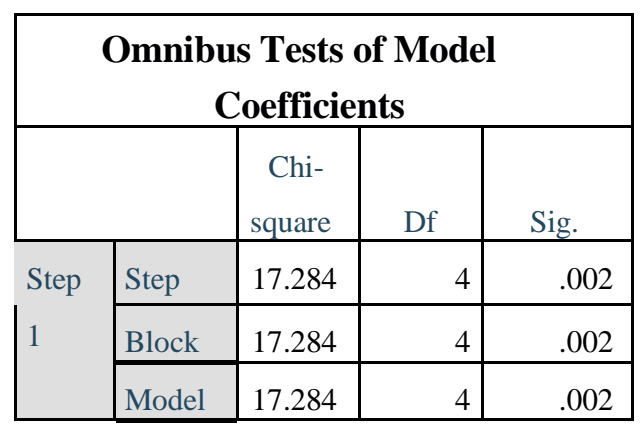

Hasil pengujian menunjukkan bahwa pada step, block, model tidak terdapat perbedaan nilai. Hal ini disebabkan metode dalam pengujian ini menggunakan metode enter, semua variabel independen bersama-sama diuji pengaruhnya terhadap variabel dependen.

$$
\text { Berdasarkan }
$$
tabel

Omnibus Test of Model Coefficients, diperoleh nilai signifikansi sebesar 0,002 Karena nilai signifikansi lebih kecil daripada 0,05 maka hipotesis 6 disimpulkan bahwa $\mathrm{H0}$ diterima, yaitu variabel independen yang terdiri dari DER, CR, Maturity dan Size secara simultan (bersama- sama) berpengaruh signifikan terhadap variabel independen yaitu peringkat obligasi.

\section{Simpulan dan Saran Simpulan}

Berdasarkan dari hasil analisis dan pembahasan serta hipotesis yang telah dilakukan dan telah diuji, makan dapat disimpulkan pengaruh variabel-variabel

independen terhadap Peringkat Obligasi adalah sebagai berikut:

1. Dari hasil penelitian diperoleh nilai koefisien untuk variabel DER adalah 0,032 dengan nilai signifikansi sebesar 0,876. Nilai ini lebih besar dari 
tingkat signifikansi $\quad 0,05 \quad(5 \%)$. Dengan demikian, Debt Equity Ratio (DER) tidak berpengaruh signifikan terhadap Bond Rating pada perusahaan sub sektor perbankan yang terdaftar di BEI tahun 2012-2017, yang berarti informasi DER

$$
\text { sebagai }
$$

pertimbangan investor untuk membeli obligasi perusahaan tidak bisa dijadikan pertimbangan oleh Pefindo untuk mengeluarkan peringkat bagi perusahaan sampel. Dengan kata lain, Debt Equity Ratio belum mendapatkan perhatian baik dari investor maupun agen pemeringkat sebagai salah satu indikator ataupun tolak ukur dalam proses pembelian serta pemeringkatan obligasi.

2. Dari hasil penelitian diperoleh nilai koefisien untuk variabel $C R$ adalah 2,104 dengan nilai signifikansi sebesar 0,057. Nilai ini lebih kecil dari tingkat signifikansi 0,05 (5\%). Dengan demikian, Current Ratio (CR) berpengaruh positif dan signifikan terhadap Bond Rating pada perusahaan sub sektor perbankan yang terdaftar di BEI tahun 2012-2017. Hal ini menunjukkan bahwa Current Ratio merupakan rasio yang dapat memberikan prediksi ke depan tentang peringkat obligasi yang akan didapatkan oleh perusahaan

berdasarkan pemenuhan kewajiban jangka pendeknya.

3. Berdasarkan hasil penelitian ini, nilai koefisien Maturity sebesar 1,345 dengan nilai signifikansi 0,139 . Nilai ini berada di atas tingkat signifikansi minimal yaitu $0,05(5 \%)$. Dengan demikian, Maturity tidak berpengaruh signifikan terhadap Bond Rating pada perusahaan sub sektor perbankan yang terdaftar di BEI tahun 2012-2017. Hal ini menunjukkan bahwa peringkat obligasi tidak dipengaruhi oleh maturity.

4. Berdasarkan hasil penelitian ini, nilai koefisien Size sebesar $-0,316$ dengan nilai signifikansi 0,245 . Nilai ini berada di atas tingkat signifikansi minimal yaitu $0,10(10 \%)$. Dengan

demikian, Size berpengaruh negatif dan tidak signifikan terhadap Bond Rating pada perusahaan perbankan yang menjadi sampel, yang berarti besarnya ukuran perusahaan sangat mempengaruhi peringkat obligasi yang diberikan. Hal ini dapat ditunjukkan pada sebagian besar perusahaan sampel yang diuji memiliki peringkat obligasi yang investment grade, yang artinya perusahaan dengan size yang kecil cenderung mendapatkan peringkat obligasi dengan

kategori investment grade.

5. Berdasarkan hasil perhitungan regresi logistic yang ditunjukkan dengan Omnibus Test of Model Coefficients, memberikan hasil nilai signifikansi sebesar 0,002. Dengan nilai signifikansi 0,002 di bawah nilai level kesalahan alpha 0,05 menunjukkan bahwa variabel DER, CR, Maturity, dan Size memiliki pengaruh terhadap Bond Rating pada perusahaan sub sektor perbankan yang terdaftar di BEI tahun 20122017. Hal ini dapat dilihat dari pengujian secara simultan yang menunjukkan bahwa seluruh variabel independen secara 
bersama-sama

berpengaruh

signifikan tehadap peringkat obligasi perusahaan perbankan yang terdaftar di BEI.

\section{Saran}

Berdasarkan kesimpulan di atas terdapat beberapa saran yang dapat diberikan sebagai berikut:

1.Hasil penelitian ini diharapkan mampu menjadi bahan evaluasi bagi bank terkait dengan Bond Rating dan hubungannya dengan DER, CR, Maturity, dan Size sehingga pihak bank bisa melakukan pengolahan dengan baik.

2. Bagi penelitian berikutnya diharapkan menambah/ mengubah rasio keuangan lainnya sebagai variabel independennya, karena sangat dimungkinkan rasio keuangan lainnya yang tidak dimasukkan dalam penelitian ini berpengaruh terhadap Bond Rating dan diharapkan juga menambahkan rasio non keuangan lainnya.

3.Bagi peneliti selanjutnya diharapkan memperpanjang periode pengamatan agar hasil penelitian lebih maksimal dalam menjelaskan keadaan yang sesungguhnya pada saat ini.

4. Bagi investor, sebaiknya membeli obligasi yang memiliki peringkat investment grade karena memiliki tingkat keamanan yang tinggi. Dan juga memperhatikan CR, Maturity, dan Size.

5. Penelitian ini menggunakan sektor perbankan sebagai sampel. Akan lebih baik jika penelitian selanjutnya menggunakan sektor lain sebagai sampel agar hasil penelitian yang didapatkan berasal dari perusahaan yang berada di berbagai sektor, tidak hanya perbankan.

\section{DAFTAR PUSTAKA}

\section{Buku}

Bodie et al. 2016. Manajemen Portofolio dan Investasi. Salemba Empat.

Bringham dan Houston. 2012. Fundamentals of Financial Management. Salemba Empat.

Darmadji, Tjiptono dan Hendy $M$ Fakhruddin. 2011. Pasar Modal di Indonesia. Salemba Empat.

Fahmi, Irham. 2012. Analisis Laporan Keuangan.

Cetakan Ke-2. Bandung: Alfabeta.

Fauziah. 2014. Likuiditas, Leverage dan Umur Obligasiterhadap Prediksi Peringkat Obligasi. Jakarta: Gramedia Pustaka Utama.

Hery. 2017. Analisis Laporan Keuangan Integrated and Comprehensive Edition. Jakarta: Grasindo.

Hermanto, Bambang dan Mulyo Agung. 2015. Analisa Laporan Keuangan. Jakarta: Lentera Ilmu Cendekia. 
Horne, James C Van dan John M Wachowicz. 2013. PrinsipPrinsip Manajemen Keuangan. Edisi 13. Buku 2. Jakarta: Salempat Empat.

Husnan, Suad dan Enny Pudjiastuti. 2011. Dasar- Dasar Manajemen

Keuangan. Yogyakarta: UPP STIM YKPN.

Iska, Sukri. 2012. Sistem Perbankan Syariah di Indonesia dalam Perspektif Fikih Ekonomi. Yogyakarta: Fajar Media Press.

Kasmir. 2011. Analisis laporan Keuangan. Jakarta: Rajawali Pers.

Krantz. 2009. Fundamental Analysis for Dummies. New Jersey: Penerbit John Wiley \& Sons, Ltd.

Keown et,al. 2011. Manajemen Keuangan: Prinsip dan Penerapan. Edisi Kesepuluh. Jilid 1. Jakarta: Indeks,

Munawir, S. 2010. Analisis Laporan Keuangan. Edisi Keempat. Cetakan Kelima Belas. Yogyakarta: Liberty.

Magreta dan Nurmayanti. 2009. Faktor-Faktor yang Mempengaruhi Prediksi Peringkat Obligasi Ditinjau dari Faktor Akuntansi. Jakarta: Grasindo.
Purnomo. et al. 2014. Pasar Uang dan Pasar Valas. Jakarta: Gramedia

Pustaka Utama.

Rukmana. 2016. Pengaruh Rasio Keuangan dan Ukuran Perusahaan (Size) terhadap Peringkat Obligasi. Yogyakarta: Fajar Media Press.

Silaen, Sofar. 2018. Metodologi Penelitian Sosial untuk Penulisan Skripsi dan Tesis. Edisi Revisi. Jakarta: In Media.

Sudana. 2015. Manajemen Keuangan Perusahaan. Jakarta: Erlangga.

Tandelilin, Eduardus. 2010. Portofolio dan Investasi Teori dan Aplikasi. Edisi Pertama. Kanisius. Yogyakarta:

Wijaya, David. 2017. Manajemen Keuangan Konsep dan Penerapannya. Grasindo.

Website

Bursa Efek Indonesia. Laporan Keuangan. www.idx.com. (Diakses pada Januari 2020).

Otoritas Jasa Keuangan. Lembaga Pengawas Industri Jasa Keuangan. Www.ojk.go.id. (Diakses pada Januari 2020).

Pefindo. Corporate Ratings. www.pefindo.com. (Diakses pada Januari 2020). 